\title{
Sustainable agriculture: $A$ process at the community level
}

\author{
Paul B. Martin and Peggy Prather
}

Key words: Community development, rapid appraisal, rural development, sustainable process

As we interact with others working in sustainable agriculture around the country, we see an obvious gap in people's understanding of differing attitudes towards sustainable agriculture. Many seem to equate the concept to an inventory of appropriate technologies for a particular agroecological zone. Some, generally those labeled environmentalists, think of it in terms of conservation or preservation of natural resources that may be affected by agriculture. Consumer advocates usually think of it in terms of agricultural food products that contain no synthetic chemicals harmful to human health and that are raised without polluting the environment or depleting natural resources.

We prefer the scope of Harwood's (1990) definition of sustainable agriculture, i.e., one "that can evolve indefinitely toward greater human utility, greater efficiency of resource use, and a balance with the environment that is favorable both to humans and to most other species." Such a normative definition of sustainable agriculture implies a number of features about society and environment that go well beyond the limits of what are commonly considered communities and includes the concept of carrying capacity and equitable distribution of natural resources.

We believe that characteristics of sustainable agriculture are: that it involve whole communities; that it should be dependent on few external inputs; that it not require continuous crisis management; and that it should serve the needs of all members of the community, including the poorest. To convey this concept, we prefer the phrase conservation and sustainable community development (CSCD) (modified after Brundtland, 1987).

The opinions herein are of the authors and do not necessarily reflect the policy of the Texas Department of Agriculture.

Paul B. Martin was Coordinator and Peggy Prather was Research Analyst, Sustainable Agriculture, Texas Department of Agriculture, Austin, TX 78711 from 1988-90. Paul is currently staff entomologist, Texas Department of Agriculture, Austin TX 78711, and Peggy is currently Education and Project Director for Texas and Oklahoma, Center for Holistic Management, Albuquerque, NM 87914.
We feel that it is more effective in communicating the whole concept and expresses the urgency of conserving resources better to provide opportunity for lasting development towards intra- and inter-generational equity and a building of real community.

Another concern is the excessively technological focus in much of the current rhetoric of sustainable agriculture, for example, emphasis on specific alternative production practices that are alternatives, to be sure, but still reflect a technologicalfix mindset. We believe our efforts should be invested instead in a search for a sustainable framework in which to operate. This has been said many times before (e.g., Altieri, 1988; Sherman, 1990) and was recently laid out well by Enshayan (1990). Therefore, we feel strongly that those who are involved in sustainable agriculture efforts must pay more attention to the process in which they are involved. This sustainable development process should be regularly evaluated to determine if, indeed, it includes the following essential features:

- historical background of economic and social development in a specific community

-assessing of local natural and human resources

-defining community boundaries and determining need for action

-team building and leadership development

-goal setting, policy development, and planning action steps

-testing management tactics

-financing strategic actions

-measuring sustainability, analyzing and evaluating, adjusting and replanning

-and quality continuing education

The results must also be examined to ascertain that the process is indeed moving the system towards sustainability.

Knowledge of the historical background provides the footing

Continued on page 48

American Journal of Alternative Agriculture 
upon which a foundation of sustainable development can be built-it can provide insight into both the capabilities and limitations of the natural and human resource. Assessment of the current natural/human resource base (e.g., via "Rapid Appraisal" or Hildebrand's (1981) "Sondeo") further reveals the foundation upon which a sustainable economy can be based. Next it is essential that some flexible ground rules be established as to the boundaries, structure, goals, and policies under which the community will function. Finally, the community must develop the capability of measuring sustainability, which includes indicators of local socioeconomic conditions, succession, mineral cycles, water cycles, and energetics, to determine if they truly are on the road to sustainable development. If a process such as this doesn't take place, we will continue to be entrapped and bogged down with "the end justifies the means," "technological fix," "it's the public perception that counts," "they're the bad guys," "those terrible, nasty chemicals," and other unhelpful rigidities that have plagued past efforts to deal with an ecological approach to whole systems living.

Until recently, we generally have referred to our efforts as conservation and sustainable rural development (CSRD) and often will continue to do so. However, use of the word "rural" may distract from the necessary partnerships required for a truly sustainable agriculture, which include partnerships between cities and the country, between farmers/ranchers and urbanites. A rural community includes basic biotic, soil, air, water, and energy resources from which local townspeople and farm/ranch workers, managers, and owners derive their living. It encompasses not just farming, ranching, and "natural" systems relatively untampered with by humans, but also urban communities. For example, Odum and Odum (1987) showed that, in Texas, industries based on agricultural products constitute 33 percent of the Texas economy. They pointed out that "many people who live in the cities are really part of the farmbased economic system but don't realize it." Krupicka et al. (1988) further discussed implications of conventional usage of the term "rural" and stressed that USDA analysts seriously underestimate the importance of agriculture to communities.

Nevertheless, because we believe that effective dialogue, trust, partnerships, and team building are so important in moving toward a sustainable economy, we have replaced the word rural with the more generic term community. We are certain that a spirit of community involving cooperation, leadership development, consensus building, and empowerment of the poor is essential for advancing toward relatively sustainable systems.

Similar processes are being developed and utilized by World Neighbors, Appalachia-Science in the Public Interest, the Uganda Rural Development and Training Program, Coordination in Development, Inc., Volunteers in Technical Assistance, and the Latin American Consortium on Agroecology and Development (CLADES). These processes are founded on communication and goals and bring people together to achieve a better quality of life. We believe that such a process is essential for developing policies and strategies supporting long-term sustainability.

\section{References}

1. Altieri, M. A. 1988. Beyond agroecology: making sustainable agriculture part of a political agenda. Amer. J. Alternative Agric. 3(4):142-143.

2. Brundtland, G. H. 1987. Our Common Future: the World Commission on Environment and Development. Oxford University Press, Oxford, Great Britain. 400 pp.

3. Enshayan, K. 1990 . Business as usual? J. of Soil and Water Conservation 45(3): 166.

4. Harwood, R. R. 1990. A history of sustainable agriculture. In C. A. Edwards, R. Lal, P. Madden, R. H. Miller, and Gar House (eds.). Sustainable Agricultural Systems. Soil and Water Conservation Society, Ankeny, Iowa. pp. 3-19.

5. Hildebrand, P. 1981. Combining disciplines in rapid appraisal: the Sondeo approach. Agricultural Administration 8(6):423-432.

6. Krupicka, R., P. Funk, and G. Severens. 1988. Response to natural resource paper: North Central region. In R. D. Knutson and D. U. Fisher. Focus on the Future: Options in Developing a New National Rural Policy. Proc. Rural Development Workshops. Texas Agric. Ext. Ser. pp. 218-223.

7. Odum, H. T., and E. C. Odum. 1987. Ecology and economy: "emergy" analysis and public policy in Texas. Lyndon B. Johnson School of Public Affairs. Policy Research Project Report 78. University of Texas, Austin, Texas. $178 \mathrm{pp}$.

8. Sherman, Richard. 1990. The meaning and ethics of sustainability. Environmental Management 14(1):1-8.

\section{EPA may ban pesticide}

EPA scientists have recommended banning the sale of parathion, one of the most poisonous pesticides used in American agriculture. It is used on fruits, vegetables, nuts, and grains, and has poisoned more than 650 field workers since 1966 , of whom at least 100 have died. New studies show that parathion could be a hazard to people and wildlife at a distance from farms because it drifts in the air and can linger in fog. Trace amounts may be ingested by consumers because of residues on vegetables. EPA will decide soon either to ban all of the pesticide or just some uses of it or take no action at all. 